УДК $811.161 .2 ’ 373$

А. С. Іншаков

\title{
НАЗВИ НА ПОЗНАЧЕННЯ АХРОМАТИЧНИХ КОЛЬОРІВ У ПРАСЛОВ'ЯНСЬКІЙ МОВІ
}

\begin{abstract}
Іншаков А. Є. Назви на позначення ахроматичних кольорів у праслов' янській мові.

Дослідження історії словникового складу української мови неможливе без 3'ясування становлення окремих семантичних груп лексики, зокрема кольоративів. У статті розглядаються найменування ахроматичних кольорів у праслов'янській мові. За даними джерел зафіксовані кольоролексеми білий, чорний, сірий та їхні похідні.
\end{abstract}

Ключові слова: кольороназва, лексеми білий, чорний, сірий, кольоратив, похідні слова, абстрактні лексеми.

Иншаков А. Е. Наименования для обозначения ахроматических цветов в праславянском языке.

Исследование истории словарного состава украинского языка невозможно без выяснения становлення отдельных семантических групп лексики, в частности колоративов. В статье рассматриваются наименования ахроматических цветов в праславянском языке. За данными источников зафиксированы цветонаименования белый, черный, серый и их производные.

Ключевые слова: цветонаименование, лексемы белый, черный, серый, колоратив, производные слова, абстрактные лексемы.

Inshakov A. Ye. Names to describe achromatic colors in Proto-Slavic language.

Research the history of the vocabulary of the Ukrainian language is impossible without elucidation of Certain semantic groups of vocabulary, including koloratyviv. In the article the name achromatic colors in Proto-Slavic language. According to sources recorded koloroleksemy white, black, gray, and their derivatives.

Proto-Slavic language, vyokremyvshys of Indo-European, inherited the basic color term. Fore-slavic formed on the basis of token Indo-European roots by using the wordbuilding tools inherited from Indo-European languages and Emerging in Proto-Slavic language. Early examples of character, spreading in the Slavic languages suggest prescription derived from the base *bĕlъ. The word white in the semantic evolution changes the value to etymological derivative (metaphorical), based on his creation is the effect of visual perception (sema "Lights"). In the Common era adjective meant the color name for such a value is used in all modern Slavic languages. Conventionally, the ego can be considered Pervin (despite metaforichnist ego origin), the chronological framework of the study the initial stages of World Health Report Common (or Slavonic) period. With roots in antiquity protein complex fixed low prikmetnikiv Slavonic type. Derivative imenniki existed, verb, adjective of color from black, matching complex derivatives. From the root "si-/*sei- convulsive formation later shryi adjective, verb like shine "blyskuchiyi shining". Of Slavonic form came koloronomen gray. Color term in Old Church Slavonic monuments 
reflect later Slavonic period. Analyzed a number of sources confirm the names of koloronomeniv derivatives, complex derivatives.

Key words: color term, token white, black, gray, koloratyv derived words, abstract tokens.

Українська історична лексикологія починає становлення 3 50-х рр. ХХ ст. Цьому сприяє історико-словникова база, що невпинно зростає, видання писемних пам'яток. Загальний огляд історії основних груп лексики подано в академічній праці «Історія української мови. Лексика i фразеологія» (К., 1983), у статтях Л. Булаховського, Д. Гринчишина, А. Критенка, О. Купчінського, Г. Півторака, В. Русанівського, І. Чепіги та ін. Питання історії становлення та розвитку окремих тематичних груп лексики на різних етапах розвитку мови постійно привертають увагу мовознавців: роботи С. Бібли, Г. Войтів, О. Зеленської, Г. Миронової, І. Сокола, П. Чучки, С. Яценка та ін. Останні кілька десятиліть увага вітчизняної та зарубіжної лінгвістики сконцентрована на вивченні окремих семантичних груп словникового складу мови. Повне дослідження історії лексичного складу української мови неможливе без з'ясування історії окремих тематичних груп лексики.

У мовознавстві при вивченні лексем на позначення кольору виокремлюють основні напрями: функціональний, лексикосемантичний та тісно пов'язаний із ним когнітивний, граматичний, порівняльний та історичний, актуалізований у роботах О. Іссерлін, Н. Бахіліної, Ю. Норманської, І. Садикової, М. Чікало, В. Горобця, Л. Ткач, Р. Алімпієвої. Ці автори досліджують історію кольороназв, процес формування окремих груп та їх склад у різні періоди розвитку мови, визначають співвіднесеність кожного найменування кольору 3 предметом-еталоном. Такі знання необхідні, бо на них грунтуються сучасні теорії вивчення кольороназв.

В історико-етимологічному аспекті вивчали слов'янські лексеми на позначення кольору Г. Герне, А. Заремба, П. Хілл. Семантичне поле російських кольороназв досліджували В. Москович, Н. Пелевіна, В. Юрик. У 60-х роках з історії кольороназв були захищені дисертації на здобуття наукового ступеня кандидата наук Л. Грановської, М. Суровцевої. В україністиці однією із перших грунтовних спроб системного діахронного аналізу групи назв кольорів писемної української мови XIV-XVIII ст. є дисертація М. Чікало. Джерельною ๑ А. Є. Іншаков, 2016. 
базою цієї роботи стали три лексичні картотеки відповідного періоду, які зберігаються в Інституті українознавства ім. І. Крип'якевича АН України.

Праці, присвячені кольороназвам, мають здебільшого фрагментарний характер, оскільки аналіз функціонування кольоролексики переважно подано в синхронному аспекті. Однак діахронічне дослідження кольороназв, зокрема праслов'янського періоду, є важливим для процесу становлення, функціонування відповідної тематичної групи, виявлення закономірностей формування історичної лексикології української мови загалом. Це й зумовило вибір теми статті та іï актуальність.

Праслов'янські назви якостей, успадковані з індоєвропейської, $є$ позначеннями небагатьох кольорів: прасл. rudъ «червоний, темночервоний»; прасл. žьltъ «жовтий»; прасл. *ръlvъ «половий»; прасл. с̌ьrnъ «чорний» [72, с. 24-25].

Праслов'янські лексеми утворені на основі праіндоєвропейських коренів за допомогою словотворчих засобів, успадкованих із праіндоєвропейської мови та нововиниклих у праслов'янській мові, напр.: прасл. bе̌lъ(jb) «білий» - bělavъ(jb) «білуватий», bělěti(sę) «біліти», bélica «тварина або рослина, плід, річ білого кольору», bělidlo «місце біління тканини, білило», běli(z)na «білизна», bělobokъ(jb) «білобокий», *bělobordъ(jb) «білобородий» та ін., bělostь «білизна, білість», bělъkъ «білок», bělbmo «більмо» та багато ін. [72, с. 26].

Ранній характер наведених номенів, поширення у слов'янських мовах (польській, чеській, словацькій, сербо-хорватській, українській, російській, білоруській) свідчать про давність похідних від основи *bĕlb, зокрема іменників - дериват із суфіксом -ica: *bĕlica у слов'янських мовах на позначення «вівця, риба, слива, біла рослина, тварина білої масті, пшениця, яблуня, сорт грунту, картоплі, черешні, яблук, вишивки, яйце, білила, жінка з білою шкірою, біла глина», староукраӥнське бъличя «білка, шкура білки» (Тимч I 170), «крейдяний грунт» (Гр I 65), «білка» (O I 80); іменне похідне *bĕlidlo від основи дієслова *bĕliti із суфіксом -(i)dlo - д.-p. б

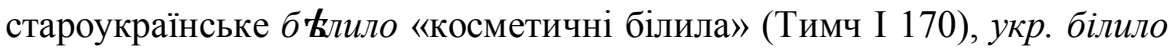
«біла фарба, все, чим можна білити, убіляти» (Гр I 65); похідний іменник із суфіксом -ikъ - *bĕlikъ пор. укр. білик «сталевий дворучний 
різець для очистки шкір», «самець білки» (Гр I 65); дериват із суфіксом -ina - *bĕlina позначав абстрактну якість («білизна»), що послужило основою для семантичних реалізацій в окремих слов'янських мовах - «білий жир», «біле полотно», «білий шар деревини», «біле м'ясо», «біле тіло», «сивина», «сорт винограду», «білила», «біла пляма», «більмо» та ін., зокрема, див. укр. білина «білизна».

Функціонально близьке до слова *bĕlina похідне із суфіксом -izna- *bĕlizna $з$ еволюцією семантики від загального значення «білий колір» до конкретних значень у різних слов'янських мовах, зокрема староукраїнське збірне б (Тимч I 170), укр. білизна (Гр I 64). Сполучення -os-tb із суфіксів -es$(-o s)$ i -tb отримало в слов'янських мовах широке поширення: воно дає абстрактні назви, похідні від прикметників: в [133, с. 296]. Протягом історії слов'янських мов розвинулися утворення, походження яких не зовсім ясне: для позначення осіб, живих істот уживаються утворення на -asъ або на *-ašjb, напр., від в t九ь - n. białas (biełas) або серб. бёла̄м (бјёла̄м) [там само, с. 299].

Автори ЭССЯ до праслов'янського фонду відносять дериват із суфіксом -ostb - *bĕlostb, cm.-cл. б қлость «білизна, чистота», д.-p.

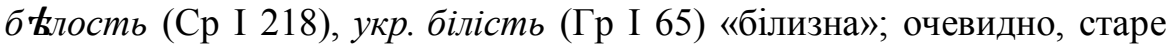

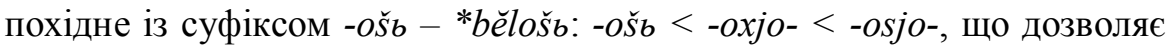
припустити давне йотоване похідне від флективного *bēlos (пор. укр. похідне білошка «порода круглих білих слив», «жартівливо: кава 3 молоком» (Гр. I 67); похідне із суфіксом -ota - *bĕlota (д.-p. бълота (Cp I 218); похідне із суфіксом -Qg- - *bĕloga / *bĕlogъ (укр. білуга (Гр I 67) «білуга»); похідне із суфіксом -иха - *bӗluха (укр. білуха (Гр I 67) «білолиця, біла як сніг жінка, блондинка»); похідне із суфіксом -ъка - *bӗlъка д.-p. б староукраїнське б $\mathbf{k} л к а$ (Тимч I 170) «білка, шкірка білки», укр. білка (Гр I 65) «білка», «рослина» (припущення щодо походження етимології слова див. ЭССЯ II 82); похідне із суфіксом -ъкъ - *bĕlъkъ, д.-p.

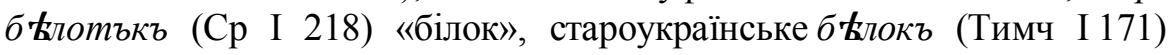
«білок (у яйці)», «біла частина лимонної шкірки», укр. білок (Гр. I 66) «білок очей», «білок яєчний». Форми на -t- на кшталт белтък, б $\mathbf{k} л о т ъ к ъ-$ реконструйовані з праформи *bĕlъкъ, їхня фонетична риса вторинна під впливом *žbltъкъ «яєчний жовток» (ЭССЯ II 83).

๑ А. Є. Іншаков, 2016. 
Від прикметника *bĕlъ утворений зі збірною функцією іменник iз суфіксом -j- - *bĕlb. У різних слов'янських мовах він має значення «ковдра, більмо, білила, мука, білок, жир, білизна, риба, щось біле», д.-p. б $\mathbf{k} л ь$ (Сp I 219) «біле поле, основний колір тканини», б $\mathbf{k} л ь$ (там само) «білило», староукраїнське б $\mathbf{k} л ь$ (Л3 95) «біла тканина», б (Тимч I 172) «білі нитки», укр. біль (Гр I 67) «білі нитки для шиття», «частина дерева, що йде безпосередньо за корою», «білизна», «сало»; іменник *bĕlbje - збірне похідне із суфіксом -ьје (див. укр. білля (Гр I 65) «білила»); іменник *bĕlbmo - похідне із суфіксом -ьто від прикметника *bĕlъ (або, можливо, від дієслова *bĕliti) через рідкісність i давню непродуктивність, безумовно, праслов'янське утворення (припущення щодо етимології деривата див. ЭССЯ II 86) староукраїнське б $\mathbf{k} л м о$ (Тимч I 170) «більмо», билмо (там само 89), укр. більмо (Гр I 67).

Похідне дієслово 3 основою на -ё-ti - *bĕlĕti(sę) див.

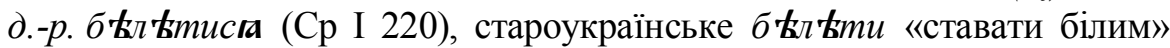
(Тимч I 172), укр. білітu; *bĕliti - похідне дієслово із суфіксом -iti, cm.-

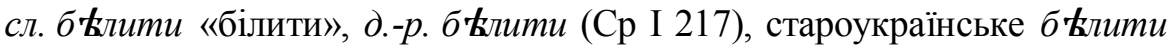
«білити» (Тимч I 170), укр. білити «білити, зафарбовувати в білий колір», «білити полотно (на сонці)», «убіляти (вмивати)» (Гр I 65).

Серед похідних дериватів праслов'янського лексичного фонду були наявні прикметники із суфіксом -as - *bĕlas- (пор. укр. біластий iз вторинним нарощенням суфікса -t-). Див.: ч. bĕlasy «світлий, голубий», n. biatasy «біластий», укр. іменник білас «рослина» (Гр. I 64); прикметник білястий «білуватий, який біліє» (Гр I 68); *bĕlavъ(jb) із суфіксом -av-, пор. укр. діал. белавий, білавий «голубий», укр. діал. білавий «блондин» (Гр I 61), білявий; *bӗlъ(jb) cm.-сл. б $\mathbf{k} л ь$ «білий», д.-p. бъла «білка», «мілка монета» (Cp I 217), староукраїнське б қлый (Тимч I 172) «білий», «чистий», «сивий»; бильй (Тимч I 90), укр. білий (Гр I 64) «білий», «чистий». Праслов'янське *bĕlъ близьке до реконструйованого кельтського *belos «світлий, блискучий». Етимологи зближують слов'янське *bĕlъ 3 давньоіндійським bhālam «блиск». Стара етимологія слов'янського слова мотивується, на думку авторів ЭССЯ, дифтонгічною природою

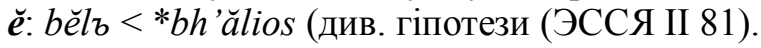

ЭССЯ фіксує цілу низку складних прикметників праслов'янського типу. Очевидна давність таких ад'єктивно$-55-$

(с) А. Є. Іншаков, 2016. 
субстантивних складних слів: *bĕlobokъ(jb) утворене 3 *bĕlъ i *bokъ (див. білобокий (Гр I 65) «із білими боками»); *bĕlobordъ(jb) - 3 *bĕlъ i основи імені *borda (див. білобородий (Гр I 65) «із білою бородою, білобородий»); *bělobrъvъjb - 3 *bělъ і ад'єктивно вжитої іменної основи - *brzvъ (див. білобровий (Гр I 65) «із русими бровами, білобровий»); *bĕlogolvъ(jb) походить із *bĕlъ та основи імені *golva (див. білоголовий «з русою або сивою головою»); *bĕlogrivъ(jb) - 3 *bělb і ад'єктивно вживаної іменної основи *-grivъ (див. укр. білогривий (Гр I 66) «з білою, світлою гривою»); *bĕloxvostъ(jb) - 3 *bĕlb $i$ *xvostb (укр. білохвостий (Гр I 67) «3 білим хвостом»); *bĕloklenь утворене 3 іменного складання *bĕlъ i *klenъ (укр. діал. білоклень); *bĕlokridlъ(jb) - 3 *bĕlъ і ад’єктивно вживаної іменної основи *kridlъ (укр. білокрилий (Гр I 66) «з білими крилами»); *bĕlolicbjb - 3 основ *bĕlъ та *likb, *lice (укр. білолиций (Гр I 66) «3 білим лицем, білолиций»); *bĕlonogъ(jъ) походить від *bĕlъ та основи імені *noga (укр. білоногий (Гр I 66) «білоногий»); *bĕlookъ(jb) - 3 *bělb та *oko (укр. білоокий); *bĕloqsъ(jb) - 3 *bĕlb та *Qsъ (укр. біловусий (Гр I 65) «з білими, світлими вусами», староукраїнське прізвище XVI ст. Белоус); *bĕlorqkb(jb) утворене 3 *bĕlъ та *rqka (укр. білорукий (Гр I 67) «білорукий»); *bělověža - складанням *bělъ та *věža (укр. Біловіж «назва села»); *Bĕlovoldъ - семантика цього

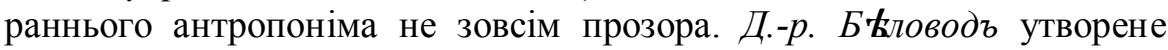
складанням основи *bĕlъ та іменної віддієслівної основи *-volds (*voldĕti); *bĕlovolsъ(jb) утворене 3 *bĕlъ та *volsъ (укр. біловолосий (Гр I 65) «біловолосий»); *bĕlozorz(jb) - складання основ *bĕlъ та *zor (укр. білозор (Гр I 66) «рослина», білозорий (там само) «той, хто має світлі очі»); *bĕlozQbъ(jb) - 3 *bĕlъ та *zQbъ (укр. білозубий (Гр I 66) «білозубий»); *bĕlbgordъ д.-p. Б Блъгород. Отже, із коренем біл- у давнину фіксувалися переважно похідні іменники, дієслова, складні прикметники.

Прасл. *⿻̌ььиъ - архаїчне кольоропозначення ще 3 дослов'янської епохи. Лексема найбагатозначніша з усіх кольороназв, спільнослов'янська й має відповідники в інших мовах: укр. чорний, рос. черный, блр. чорны, д.-р. чернъ, ст.-сл. чрънъ, болг. чърн, черен, схв. ирн, слвн. с̌rn, ч. с̌еrny, сли. с̌іегny, n. сzаrny, в. луж. с̌огnу, полаб.

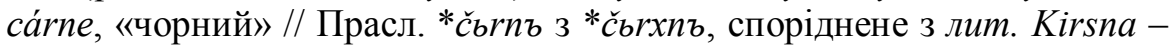
назва річки, д.-прус. кirsnan «чорний», д.-інд. krsnas «чорний» та ін.

(ㄱ А. Є. Іншаков, 2016. 
(Ф IV 346); скр. kяrsnah, д.-nрус. kirsnan «чорний», пор. слов. *с̌ьrnъ : cт.-сл. чрънъ, рос. чёрный та ін. [133, с. 73].

Розглядуваний номен може походити 3 i.-є. *kĭrno-, деякі

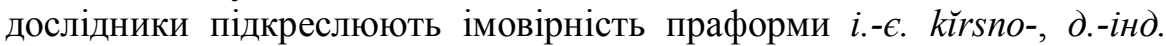
*krsna - «чорний, темний», д.-npyc. kirsnan. Відповідно прасл. *с̌ьrnъ

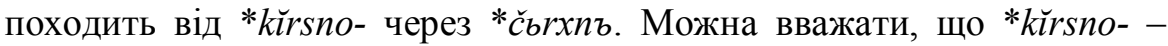
вторинна словотвірна форма, бо йде нанизування формантів - s-n-. Розвинулася з $\partial .-p$. чернъ, чьрныли $\mathbf{e}>\mathbf{0}$ після шиплячого, кінцевий $-\mathbf{и}>$ -й. Давня руськоукраїнська форма чьрнъ походить із праслов'янської

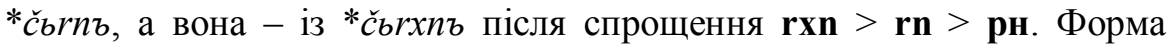

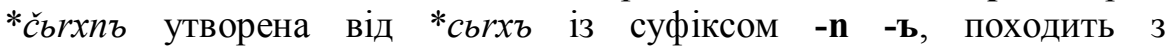
індоєвропейської *kirs-, на слов'янському грунті змінилися $\mathbf{k}>\check{\mathbf{c}}$ перед голосним переднього ряду. Свистячий -s- утрачається тільки у складних сполученнях. Після $\mathbf{r}$ він зник у *с̌ьrsnъ (cm.-сл. чрънъ, poc. чорний та ін.), пор. скр. k.rsnah, д.-npyc. kirsnan [там само, с. 112]. Рефлекс *br засвідчений у мовах: скр. krsnah «чорний», д.-прус. kirsnan, слов. *čbrnъ: cт.-сл. чрънъ, рос. черн- (чёрен), серб. ирн, слов. črn, чес. černy (давнє črny), n. czarny (czern «чорнота») [там само, c. 61]. Суфікс -ica 3 *-ika жіночого роду, виник через приєднання *-ka до давнього утворення жіночого роду на -і-: чръннца «монахиня» поряд із чръньць «монах» [там само, с. 291]. Iз суфіксом -іса функціонували омонімічні утворення: *čsrnica «шовковиця» (ЭССЯ IV 152), укр. черниця, чорниця «ожина» (Гр IV 470).

Давня лексема чьрнило за походженням праслов'янська, калька грецького melan «чорний», «чорнило». Пізніше від нього був утворений номен «меланхолія», «сумний настрій, депресія», буквально «чорна жовч». Лексема чорнило спершу мала форму *čbrnidlo > чьрнило «те, чим чорнять», утворена від дієслова *čbrniti > чорнити з суфіксом -dlo, вона похідна від прикметника *čbrnъ «чорний» (ЦЭСРЯ 480); *čbrnidlo cm.-сл. чрьнняо «чорнило», иясл. чьрння⿻, чрьннио, черннио «чорнило, чорна фарба для письма», українське чорнило «чорна фарба, що використовується для фарбування тканин та ін.» (ЭССЯ IV 152).

Від *črnavъ(jъ) утворені: д.-p., цсл. чьрндва «хвилювання, тривога», «покаяння» (XIV Cp III 1566-1567), укр. (субстантивоване) чернява «чернь, натовп людей» (Гр IV 458). Ця форма - прикметник, похідний від *с̌ьrnь $з$ суф. -av- (ЭССЯ IV 151). 
Похідна лексема від прикметника *čьrnъ 3 суф. -adь -

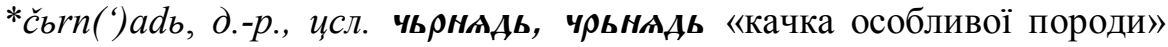
(Cp III 1567): стрежаше е гоголемъ на водь чаицами на струяхъ, чрьнядьми на в $\mathbf{k} m p \mathbf{k} x$ (XII CПI 42) (пор.: укр. черніт «чорна вовняна пряжа»). Суфіксальне утворення чернядка, чернетка означає «плахта чорного кольору» (Гр IV 458).

Від прикметника *čsrnь утворилися дієслова *čsrněti, *čsrniti (ЭССЯ IV 153).

Складанням основ утворені композити:

- *čbrnobylb, *čbrnobylb, *čbrnobylbje від складання основ *čbrnъ і *bylb, *bylbje: ...и $\mathbf{k x a ~ с ~ л о в о в ъ ~} \boldsymbol{\boldsymbol { w }}$ Чернобыла в Торизькыи (1193 ЛI 678) (пор.: укр. рослина чорнобил, чорнобиль (Гр IV 470), діал. чернобіль (там само 458);

- *čbrnogolvъ від сполучення основ *čbrnъ і *golva. Утворення давнє, бо універбація проведена не тільки словотвірно, але й семантично (пор.: чорноголовий - прикметник, також назва птаха (там само 471);

- від складання основ *čsrnъ і *klenь - *čbrnoklenь (укр. чорноклен «чорний клен» (там само);

- від складання основ *čbrnъ i *kosb - *čbrnokosb чорнокос, чорнокис (укр. діал. «дрозд чорний»). Це болгарсько-українська ізоглоса (болг. чернокосъ «дрозд чорний») (ЭССЯ IV 153, 154).

Дериват *čbrnyšb походить від прикметника *čbrnъ з суфіксом -уг̌ь. (пор.: давнє руськоукраїнське Чернышь - власна назва, укр. чорниш «чорний хліб (у жебраків)» (Гр IV 470).

Від прикметника *čsrnъ із суфіксом -иха/-ихъ утворене похідне *čsrnuха / *čsrnuхъ (укр. чорнуха «зовсім чорна жирна глина», «риба» (там само 472); із суфіксом -ota - іменник * čbrnota (ЭССЯ IV 154, $155)$; іменник *čbrnь (див. укр. чернь «чорний колір, чорний одяг», «чорні нитки», «чернь, простий народ») (Гр IV 458).

Мовознавці звертають увагу на відсутність давнього слова зі значенням «чорний» у більшості індоєвропейських мов, очевидно, через табуїстичну заборону (ЭССЯ IV 155-156).

Номен сірий, д.-p., ислл. сърz, походив із прасл. *хоіro-, споріднені болг. сер, слвн. ser, sera «сірий, білявий», n. szary споріднене нім. *haira-, д.-ісл. harr «сірий, сідий» (Ф III 610). 


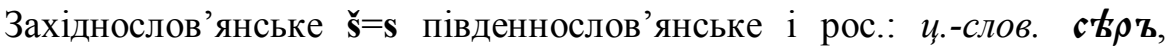
слов. sêr, рос. серый: n. szary, чес. šеry, н.-луж. šery [133, с. 80].

Сірий - це «колір, утворений від змішування чорного з білим, колір попелу». За походженням форма праслов'янська, з д.-p. с $\mathbf{k} p ы и$ (зі зміною $\mathbf{b}$ в i). Форма повного прикметника походить від праслов'янської - *sěrъ «сірий, світлий» за допомогою закінчення - blu. Вона ж утворилася з суфіксом $-r-b$, що вказував на численність ознаки, названої в корені, корінь *sе̌-(si-)<*xoi- (зміна $\mathbf{x}>\check{\mathbf{s}})$; оі $>\check{\mathbf{e}})$, що в слові сяяти (ЦЭСРЯ 375).

Пізній праслов'янський період відображають пам'ятки старослов'янські. Наприклад, лексеми, утворені від кольороназви

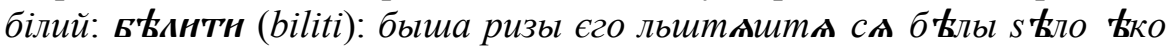

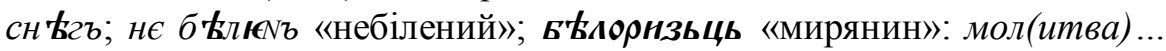

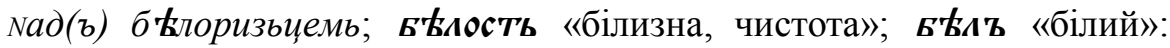
дъва мжжа въ б блахъ ризахъ; б

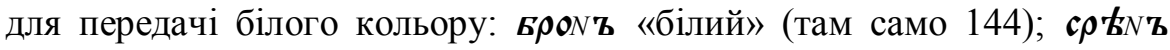
«білий»: $u$ ce коNb $c p$ tsb (там само 36 155). Близький до білого

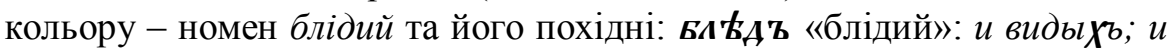

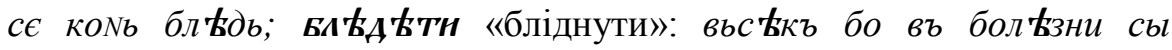
$m \mathbf{k} л \epsilon c b \mathbf{k} u$ бл $\mathbf{k} \partial \mathbf{k} \boldsymbol{3} \mathbf{k} л о$ (там само 1116 ).

Більше зафіксовано номенів, похідних від чорного кольору: чрьль штрокь пришьд(b) к нкмог (там само 48 888), синоніми та похідні від них прикметники чрzльць «чернець, відлюдник»: $c b \partial \epsilon$ чрьлєщъ Nе можєши быти; чръльчьскъ «чернечий»: шбраза чрълєчьс'ка; чръльчьство «чернецтво»: косталтила философа. Nарєчелаго въ чрьньчьство имельмь курила (там само 889); чрұлорнзьць «чернець, чорноризець, відлюдник»: чьтелиє Nadb чьрлоризьцємъ; о писмєлє Хь чрълоризиа храбра; чртлорнзьчьскъ «чернецький»: $N \epsilon$ бо бъ тъгда тоу ли сльда чрълоризъчьска; чрълорнзьскъ «чернецький»: правьюлиг чрълоризъскааго житига Nє

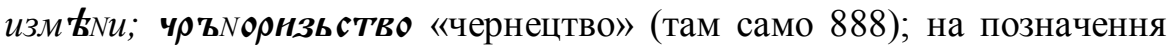
жіночої статі: чръNорнзнца «черниця» (там само); похідний іменник чрънняо «чорна фарба, сажа; чорнила» (там само 887); складний

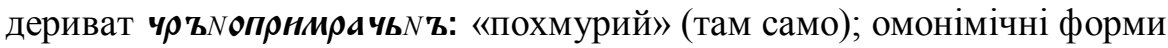

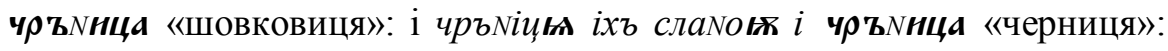
ащс к'то чрълицек окрадетъ (там само). 
Отже, праслов'янська мова, виокремившись із індоєвропейської, успадкувала основні кольороназви. Праслов'янські лексеми утворені на основі праіндоєвропейських коренів за допомогою словотворчих засобів, успадкованих із праіндоєвропейської мови та нововиниклих у праслов'янській мові. Ранній характер прикладів, поширення в слов'янських мовах (польській, чеській, словацькій, сербохорватській, українській, російській, білоруській) свідчать про давність похідних від основи *bĕlb. Слово білий у процесі семантичної еволюції змінює значення на етимологічно похідне (метафоричне), в основі творення його лежить ефект зорового сприймання (сема «сяйво»). У спільнослов'янську епоху прикметник означав назву кольору, бо 3 таким значенням уживається в усіх сучасних слов'янських мовах. Умовно можна вважати його первинним (незважаючи на метафоричність його походження), хронологічні рамки дослідження початковим етапом мають спільнослов'янський (або праслов'янський) період. Із коренем біл- у давнину фіксується низка складних прикметників праслов'янського типу. Побутували похідні іменники, дієслова, прикметники від кольороназви чорний, відповідні складні деривати. Від кореня *si-/*sei- утворений пізніший прикметник сқрын, подібно до дієслова сяяти «блискучий, сяючий». Із праслов'янської форми походить кольорономен сірий. Кольороназви в старослов'янських пам'ятках відображають пізній праслов'янський період. Проаналізовані джерела засвідчують низку похідних назв від кольорономенів, складні деривати.

\section{Література}

1. Бахилина Н. Б. История цветообозначений в русском языке / Н. Б. Бахилина. М. : Наука, 1975. - 288 c.

2. Історія української мови. Лексика і фразеологія / [за ред. В. О. Винника]. - К. : Наук. думка, 1983. - 742 c.

3. Мейе А. Общеславянский язык / А. Мейе. - М. : Изд-во иностранной литературы, 1951. -492 с.

\section{Перелік умовних скорочень використаних джерел}

Гр Словарь української мови / Зібр. ред. журн. «Киевская старина». Упорядкував, з дод. власн. матеріалу, Б. Грінченко. - К., 1907-1909. - Т. 1-4.

ЛЗ Лаврентій Зизаній. Грамматіка словєнска / Підгот. факсим. видання та дослідження пам'ятки В. В. Німчука. - К. : Наукова думка, 1980. - 56 с.

ЛІ Полное собрание русских летописей. Т. 2. Ипатьевская летопись. - М. : Изд-во восточной л-ры, $1962 .-573$ с.

( А. €. Іншаков, 2016. 
О Онишкевич М. Й. Словник бойківських говірок. - К. : Наукова думка, 1984. - Ч. $1-2$.

СПІ Ироическая п'ъснь о поход' на половцевъ уд'ъльного князя НовгородС Łверского Игоря Святославича, писанное стариннымъ русскимъ языкомъ въ поход $\mathbf{6}$ ХІІ стольтія. - М., 1800. - С. 1-48.

Ср Срезневский И. И. Материалы для Словаря древнерусского языка. - Спб., 1893-1912. - T. 1-3.

Тимч Історичний словник українського язика / За ред. Є. Тимченка. Харків-Київ : ДВУ, 1930-1932. - Т. 1. - XXIV, 937 с.

Ф Фасмер М. Этимологический словарь русского языка : В 4 т. / Пер. с нем. и доп. О. Н. Трубачева ; Под ред. Б. А. Ларина. - [2-е изд., стереотип.]. - М. : Прогресс, 1986-1987. - T. 1-4.

ЦЭСРЯ Цыганенко Г. П. Этимологический словарь русского языка : Более 5000 слов. - [2-е изд., перераб. и доп.]. - К. : Рад. шк., 1989. - 510 с.

ЭССЯ Этимологический словарь славянских языков: Праславянский лексический фонд / Под ред. О. Н. Трубачева. - М. : Наука, 1974-2007. - Вип. 1-33.

SJStSL Slovnic jazyka staroslověnskĕho. - Praha : Nakl. CSAV, 1958-1966. $1 \mathrm{~d}$; $1967-1973 .-2 \mathrm{~d}$.

Стаття надійшла до редакції 11.11.2015 p. 